\title{
PENGARUH BUDAYA ORGANISASI DAN DISIPLIN KERJA TERHADAP KINERJA PEGAWAI DI KANTOR DESA TIMORENG PANUA KECAMATAN PANCA RIJANG KABUPATEN SIDENRENG RAPPANG
}

\author{
1) Monalisa Ibrahim, 2) Eviyanti \\ Ilmu Pemerintahan, Fakultas IImu Sosial dan Ilmu Politik,Universitas Muhammadiyah Sidenreng Rappang \\ eviyanti43151093f3@gmail.com
}

\begin{abstract}
Abstrak
Penelitian ini bertujuan 1). Untuk mengetahui Pengaruh Budaya Organisasi terhadap Kinerja Pegawai di Kantor Desa Timoreng Panua Kecamatan Panca Rijang Kabupaten Sidenreng Rappang. 2). Untuk mengetahui Disiplin Kerja terhadap Kinerja Pegawai di Kantor Desa Timoreng Panua Kecamatan Panca Rijang Kabupaten Sidenreng Rappang. 3). Untuk mengetahui Pengaruh Budaya Organisasi dan Disiplin Kerja terhadap Kinerja Pegawai di Kantor Desa Timoreng Panua Kecamatan Panca Rijang Kabupaten Sidenreng Rappang. Teknik pengambilan sampel menggunakan teknik sampling jenuh dengan jumlah sampel sebanyak 46 orang. Teknik pengumpulan data menggunakan observasi, wawancara, kuesioner dan study kepustakaan. Teknik analisis data kuantitatif yang digunakan yaitu analisis tabulasi frekuensi dan analisis regresi sederhana dengan bantuan program SPSS.Berdasarkan dari hasil olahan analisis regresi linier berganda menggunakan SPSS 16.0 for windows, di ketahui pengaruh Budaya Organisasi (X.1) terhadap Kinerja Pegawai(Y) nilai t hitung 0,969 $<$ t tabel $=1,680$ dengan nilai signifikansi $0,000<$ 0,05 dengan persentase sebesar 54\%. Pengaruh Kedisiplinan (X.2) terhadap Kinerja Pegawai $(Y)$ di ketahui nilai $t$ hitung $0,420<\mathrm{t}$ tabel $=1,680$ dengan nilai signifikansi $0,000<0,05$ dengan persentase sebesar 46,3\%, dan pengaruh Budaya Organisasi (X.1), Kedisiplinan (X.2) terhadap Kinerja Pegawai $(Y)$ di ketahui nilai $t$ hitung 8,083 $>\mathrm{t}$ tabel $=1,680$ dengan nilai signifikansi 0,000 $<0,05$ dengan persentase sebesar 48\% maka dapat dikatakan bahwa hipotesis positif (Ha) diterima dan hipotesis negatif $(\mathrm{Ho})$ ditolak.
\end{abstract}

Kata Kunci : Budaya Organisasi, Disiplin Kerja, Kinerja

\begin{abstract}
This research aims 1). to find out the influence of Organizational Culture on Employee Performance at the Village Office in Timoreng Panua, District of Panca Rijang, Sidenreng Rappang Regency. 2). To find out the Work Discipline on Employee Performance at the Timoreng Panua Village Office, Panca Rijang District, Sidenreng Rappang Regency. 3). To determine the effect of Organizational Culture and Work Discipline on Employee Performance at the Village Office in Timoreng Panua, District of Panca Rijang, Sidenreng Rappang Regency. The sampling technique uses saturated sampling technique with a total sample of 46 people. Data collection techniques using observation, interviews, questionnaires and literature study. Quantitative data analysis techniques used are frequency tabulation analysis and simple regression analysis with the help of the SPSS program.Based on the results of the processing of multiple linear regression analysis using SPSS 16.0 for windows, the influence of Organizational Culture (X.1) on Employee Performance $(Y)$ is calculated $t$ value $0.969<t$ table $=1.680$ with a significance value of 0.000 $<0.05$ with a percentage of $54 \%$. Effect of Discipline (X.2) on Employee Performance (Y) is known $t$ count value of $0.420<t$ table $=1.680$ with a significance value of $0.000<0.05$ with a percentage of $46.3 \%$, and the influence of Organizational Culture (X.1), Discipline (X.2) on Employee Performance $(Y)$ is known $t$ count value of $8.083>t$ table $=1.680$ with a significance value of 0.000 $<0.05$ with a percentage of $48 \%$, it can be said that the positive hypothesis (Ha) is accepted and the negative hypothesis $(\mathrm{Ho})$ rejected.
\end{abstract}

Keywords: Organizational Culture, Performance, Work Discipline 


\section{A. PENDAHULUAN}

Manusia aktif dan selalu dominan dalam setiap kegiatan organisasi, karena manusia menjadi perencana, pelaku, penentu serta terwujudnya dalam suatu tujuan organisasi. Tujuan tidak akan terwujud tanpa adanya peran aktif pegawai meski alat yang dimiliki organisasi begitu canggih. Sejauh mana keberadaan, peran, dan kontribusi sumber daya manusia dalam mencapai keberhasilan organisasi, diperlukan pengukuran kinerja. Organisasi yang telah berhasil dan efektif merupakan organisasi dengan individu yang di dalamnya memiliki kinerja yang baik. Organisasi yang efektif atau berhasil akan ditopang oleh sumber daya manusia yang berkualitas.Menurut Mangkunegara (2004:67) dalam Robin P Simanjuntak, kinerja adalah hasil kerja secara kualitas dan kuantitas yang dicapai oleh seorang pegawai dalam melaksanakan tugasnya sesuai dengan tanggung jawab yang diberikan kepadanya.

Pelayanan yang maksimal setiap jenjang birokrasi pemerintah memiliki sumber daya manusia yang berkualitas, berintegrasi dan mempunyai kemampuan yang tinggi untuk mampu mendorong kinerja organisasi baik birolayanan maupun Satuan Kerja Perangkat Daerah (SKPD) dan setiap organisasi menghendaki karyawannya bekerja dengan mendapatkan motivasi yang tinggi terhadap pekerjaannya. Di tuntut kemampuan dengan seluruh jajaran Pemerintahan Daerah dalam mengelola sumber daya secara terencana, terutama pada sumber daya manusia sebagai tenaga pelaksana operasional pemerintahan untuk mencapai tujuan yang diharapkan.Keberhasilan suatu perangkat ditentukan oleh kemampuan mengelola dan mendayagunakan sumber daya manusia yang berada dalam Satuan Kerja Perangkat Daerah (SKPD) tersebut. Satuan Kerja Perangkat Daerah (SKPD) yang telah menggunakan teknologi canggih dalam bekerja semuanya tidak akan berguna kalau tidak didukung oleh sumber daya manusia yang berkualitas, mempunyai kemauan kerja yang tinggi untuk mencapai kinerja yang diharapkan. Apabila pegawai memiliki kesadaran bekerja optimal maka tujuan organisasi akan lebih mudah tercapai.

Salah satu faktor yang terpenting dalam organisasi yang mempengaruhi kinerja adalah budaya organisasi. Budaya organisasi bersangkut paut dengan peningkatan kinerja pegawai dalam suatu organisasi. Apabila semakin baik budaya organisasi, maka semakin besar pula dorongan para pegawai untuk maju bersama dengan organisasi. Budaya organisasi memiliki filosofinya tersendiri, cara pemecahan masalah dan pengambilan keputusan sendiri, keyakinan, perilaku dan pola pemikiran, praktek bisnis, kepribadian sendiri. Budaya organisasi dapat mempengaruhi perilaku, sikap dan efektifitas pegawai dalam organisasi tersebut.

Setiap pegawai yang ada dalam organisasi memiliki budaya yang berbeda, karena pegawai memiliki latar belakang budaya yang berbeda pula, namun dari perbedaan masing-masing pegawai tersebut akan bersatu dalam sebuah budaya organisasi. Dari budaya organisasi ini membentuk suatu kelompok yang bekerjasama dalam mencapai tujuan organisasi yang telah ditetapkan. Namun dalam proses tersebut ada perbedaan yang muncul dalam organisasi yaitu ada pegawai yang tidak bisa menerima karena bertentangan dengan budaya yang dimilikinya. Hal ini bisa berakibat lemahnya budaya organisasi, karena tidak adanya kesepakatan bersama diantara pegawai, sehingga dapat mempengaruhi kinerja pegawai itu sendiri.Faktor lain yang mempengaruhi kinerja adalah disiplin kerja. Kedisiplinan dalam suatu organisasi merupakan tolok ukur hidupnya norma, tata tertib dan peraturan organisasi yang berhubungan dengan orang-orang dalam organisasi. Disiplin yang baik merupakan tanggung jawab pegawai terhadap tugas yang diberikan. Disiplin lebih banyak berasal dari diri pegawai itu sendiri. Salah satu bentuk disiplin adalah pegawai dapat menyelesaikan pekerjaan tepat waktu.

Setiap organisasi mempunyai standar perilaku, baik tertulis maupun yang tidak tertulis yang harus dijalankan dan berhubungan dengan tugas. Organisasi mengharapkan standar perilaku dan aturan yang telah dibuat dapat dipatuhi oleh pegawai agar dapat meningkatkan kinerja pegawai, tetapi dalam kenyataan sering terjadi pegawai sebagai manusia mempunyai kelemahan yaitu kurang disiplin.Budaya adalah pola asumsi dasar ditemukan sertadikembangkan oleh kelompok tertentu 
karena mempelajari serta menguasai masalah adaptasi luar dan integrasi dalam,yang bekerja cukup baik dalam pertimbangan yang layak karena hal tersebut diajarkan pada anggota yang baru sebagai cara dipersepsikan, berpikir serta dirasakan dengan benar dalam hubungan masalah tersebut (Edgar Schein,1997:12).

Simamora dalam Hamzah B.Uno, (2014:62) kinerja adalah keadaan atau tingkat perilaku seseorang yang harus dicapai dengan persyaratan tertentu. Dalam kaitannya dengan kinerja manajemen. Kreitner dan Kinicki mengemukakan kinerja manajemen yaitu sistem perluasan organisasi yang mana manajer mengintegrasikan aktivitas denganpencapain tujuan, monitoring dan evaluasi, serta memberikan masukan dan melatih pegawai secara berkesinambungan Kreitner dan Kinicki (2007:270).Disiplin merupakan kesediaan seseorang yang timbul dengan kesadaran sendiri dalam mengikuti peraturan yang ada dalam organisasi. Menurut Davis (2002: 112) dalam Radeswandri, disiplin yaitu tindakan manajemen dalam memberi semangat pada pelaksanaan standar organisasi, hal ini sebagai pelatihan yang mengarah untuk upaya dalam membenarkan dan melibatkan pengetahuan sikap serta perilaku pegawai sehingga adanya motivasidiri pegawai dalam bekerja sama serta prestasi yang lebih baik.

Berdasarkan hasil observasi awal yang terjadi di Kantor Desa Timoreng Panua, nampak bahwa salah satu faktor yang mengakibatkan penurunan kinerja pegawai adalah disebabkan karena mempunyai masalah yang sangat kompleks didalam sumber daya manusia, khusus mengenai masalah diantanya kurangnya disiplinpegawai, dimana diantaranya pegawai belum mematuhi peraturan dan standar yang telah ditetapkan seperti kedisiplinan mengenai aturan jam kantor, seperti mereka masuk kantor setelah jam 08.00 WITA dan pulang sebelum jam 16.00 WITA, selain itu masih ada karyawan/pegawai yang tidak menaati peraturan dan tata tertib yang berlaku pada kantor, sehingga mengakibatkan kinerja karyawan/pegawai mengalami penurunan.Sehingga dengan menurunnya kinerja karyawan/pegawai maka kantor harus menerapkan kedisiplinan karyawan/pegawai, yakni dengan mematuhi segala peraturan atau tata tertib yang akan menjadi rambu-rambu yang harus dipenuhi oleh seluruh karyawan/pegawai dalam kantor. Adapun peraturan-peraturan yang akan berkaitan dengan disiplin adalah: peraturan jam masuk, pulang dan jam istirahat, peraturan dasar tentang berpakaian, dan bertingkah laku dalam pekerjaan, peraturan cara-cara melakukan pekerjaan dan berhubungan dengan unit kerja lain, serta peraturan tentang apa yang boleh dan apa yang tidak boleh dilakukan oleh para karyawan/pegawai selama dalam kantor.

Berdasarkan hasil pengamatan tersebut, peneliti mengangkat judul penelitian Pengaruh Budaya Organisasi dan Disiplin Kerja Terhadap Kinerja Pegawai di Kantor Desa Timoreng Panua Kecamatan Panca Rijang Kabupaten Sidenreng Rappang dengan tujuan untuk mengetahui Pengaruh Budaya Organisasi terhadap Kinerja Pegawai di Kantor Desa Timoreng Panua Kecamatan Panca Rijang Kabupaten Sidenreng Rappang, untuk mengetahui Disiplin Kerja terhadap Kinerja Pegawai di Kantor Desa Timoreng Panua Kecamatan Panca Rijang Kabupaten Sidenreng Rappang dan untuk mengetahui Pengaruh Budaya Organisasi dan Disiplin Kerja terhadap Kinerja Pegawai di Kantor Desa Timoreng Panua Kecamatan Panca Rijang Kabupaten Sidenreng Rappang.

\section{Konsep Budaya Organisasi}

Menurut Green Berg dan Baron sebagaimana dikutip (Sudarmanto, 2009) mengemukakan culture theory bahwa budaya organisasi adalah kerangka kerja kognitif yang terdiri dari sikap-sikap, nilai-nilai, norma perilaku dan harapan bersama yang dirasakan oleh anggota organisasi. Budaya organisasi adalah pandangan hidup organisasi yang dihasilkan melalui pergantian generasi pegawai. Budaya dalam hal ini mencakup siapa kami, apa yang kita percaya, apa yang akan kita lakukan.Budaya organisasi suatu pola dari asumsi dasar yang dapat dipahami secara bersama di dalam organisasi, khususnya dalam memecahkan permasalahan yang sedang dihadapi. Pola tersebut akan menjadi suatu yang pasti mensosialisasikan pada anggota yang baru dalam suatu organisasi.Menurut Tilaar dalam Makmur dalam Zainuddin (2017: 191) memberikan pemahaman terkait dengan 
Budaya Kerja yaitu suatu nilai moralitas yang dominan dalam rangka melakukan suatu kegiataan atau pekerjaan dalam sebuah organisasi, sehingga memperoleh dayaguna dan hasilguna baik manfaatnya untuk pengembangan organisasi itu sendiri maupun untuk mewujudkan kesejahteraan para anggota organisasi. Budaya kerja organisasi merupakan sekumpulan nilai dasar moralitas yang dapat menyinari kesadaran tanggung jawab anggota organisasi untuk melaksanakan dan menyelesaikan suatu pekerjaan yang diberikan atau dipercayakan kepada seseorang atau beberapa orang oleh organisasi.

Budaya organisasi dapat merubah perilaku pegawai sebab budaya menjadi salah satu faktor dapat berpengaruh positif ataupun negatif terhadap suatu perilaku pegawai serta organisasi itu. Budaya organisasi yang positif akan memberikan motivasi berprestasi karyawan dan efektivitas perusahaan. Sedangkan, budaya yang negatif akan bersifat kontra produktif terhadap usaha dalam pencapaian tujuan organisasi sehingga hal tersebut dapat menghambat aktivitas kerja serta motivasi pegawai. Selanjutnya lingkungan kerja dapat mempengaruhi motivasi sebab lingkungan merupakan elemen dalam sebuah organisasi yang memiliki pengaruh yang cukup kuat untuk pembentukan perilaku personal, Oleh karena itu budaya organisasi tidak hanya selalu berperan sebagai simbol filosofi perusahaan yang sifatnya abstrak dan mengawang-awang.Mc. Clelland mengatakan apabila seseorang tidak memiliki kemampuan cara untuk mencapai tujuan tertentu, maka hal kebutuhannya dalam mencapai tujuan yang diinginkan tidak terpenuhi. Apabila pegawai kurang mampu dalam hal memahami dengan budaya organisasi, maka akan sulit bagi bagi untuk dapat mempertahankan serta meningkatkan motivasinya. Karyawan dapat berprestasi karena adanya budaya orgnisasi yang sangat kuat sebab budaya organisasi mampu memberi motivasi kepada untuk menciptakan inovasi baru sesuai tujuan perusahaan (Sudarmanto, 2009).

Menurut Tilaar dalam Makmur (2017: 191) memberikan pemahaman terkait dengan Budaya Kerja yaitu suatu nilai moralitas yang dominan dalam rangka melakukan suatu kegiataan atau pekerjaan dalam sebuah organisasi, sehingga memperoleh dayaguna dan hasilguna baik manfaatnya untuk pengembangan organisasi itu sendiri maupun untuk mewujudkan kesejahteraan para anggota organisasi. Budaya kerja organisasi merupakan sekumpulan nilai dasar moralitas yang dapat menyinari kesadaran tanggung jawab anggota organisasi untuk melaksanakan dan menyelesaikan suatu pekerjaan yang diberikan atau dipercayakan kepada seseorang atau beberapa orang oleh organisasi.Menurut Hasbar Mustafa 2014: 91 ada Indikator Budaya Kerja Organisasi adalah sebagai berikut:

a. Motivasi kerja: nilai-nilai dan kebiasaan yang hidup dalam organisasi memotivasi anggota organisasi bekerja dengan ikhlas dan merasa nyaman dalam melaksanakan pekerjaannya.

b. Komunikasi: hubungan komunikasi yang terjalin baik antara pimpinan, karyawan dan masyarakat dalam organisasi.

c. Kebersamaan: kebersamaan begitu penting dalam sebuah organisasi.

d. Kepemimpinan manajer: rasa nyaman dari mitra kerja dan masyarakat yang dilayani oleh organisasi yang bersangkutan.

e. Pemahaman visi misi organisasi: terjadinya keselarasan antara budaya organisasi dengan struktur.

\section{Disiplin Kerja}

Disiplin merupakan sikap mental yang tercermin dalam perbuatan tingkah laku perorangan, kelompok atau masyarakat berupa kepatuhan atau ketaatan terhadap peraturan, ketentuan, etika, norma dan kaidah yang berlaku. Disiplin kerja adalah sikap kejiwaan individu atau kelompok yangsenantiasa hendak untuk mengikuti serta mematuhi segala peraturan yang telah ditentukan.Menurut Hasibuan (2011: 21) Kedisiplinan merupakan fungsi operatif MSDM yang terpenting semakin baik disiplin pegawai, maka akan semakin tinggi prestasi kerja pegawai yang dapat dicapai. Tanpa disiplin disiplin yang baik, akan sulit bagi suatu organisasi untuk mencapai hasil yang lebih baik".

Disiplin kerja yang baik mencerminkan rasa tanggung jawab seseorang terhadap tugas yang diberikan, Hal tersebut dapatmemotivasi gairah kerja, semangat kerja, serta terwujudnya tujuan organisasi, pegawai dan masyarakat.Menurut Heidjrachman dan Husnan (2002: 15), 
disiplin adalah setiap perseorangan dan juga kelompok yang menjamin adanya kepatuhan terhadap perintah dan berinisiatif dalam melakukan suatu tindakan yang diperlukan meski tidak adanya perintah.

Berdasarkan Peraturan Disiplin Pegawai Negeri Sipil yang tertuang dalam PP No. 53 Tahun 2010 mengatur mengenai halhal yang boleh dilakukan dan tidak boleh dilakukan oleh PNS atau mengatur laranganlarangan dan sanksi yang akan diterima oleh PNS jika melanggar peraturan disiplin PNS tersebut. Peraturan PP No. 53 Tahun 2010 harus diketahui oleh para PNS supaya dalam menjalankan tugasnya tidak seenaknya sendiri, karena bagaimanapun PNS digaji oleh negara.Veithzal Rivai dan Ella Jauvani (2011: 825), Disiplin kerja merupakan suatu alat digunakan manajer dalam berkomunikasi dengan pegawai agar bersedia untuk merubah perilaku serta upaya dalam meningkatkan kesadaran serta kesediaan seseorang taat pada semua aturan perusahaan dan norma sosial.Disiplin pegawaisangat memerlukan alat komunikasi, utamanya pada peringatan yang sifatnya spesifik terhadap pegawai yang sangat sulit untuk merubah sifat dan perilakunya. Disiplin harus ditegakkan dalam organisasi, tanpa adanya dukungan disiplin pegawai yang baik, maka akan sulit bagi perusahaan dalam mewujudkan tujuannya.Indikator-indikator disiplin kerja menurut Mangkunegara dalam Sinambela (2012:2:239) adalah sebagai berikut :

a. Disiplin Preventifyaitu adalah suatu upaya untuk menggerakkan pegawai untuk mengikuti dan mematuhi peraturan dan aturan kerja yang ditetapkan oleh organisasi. Dalam hal ini, disiplin preventif bertujuan untuk menggerakkan dan mengarahkan agar pegawai bekerja berdisiplin. Pedoman dalam melakukan tindakan pendisiplinan preventif adalah kehadiran, penggunaan jam kerja, dan tanggung jawab.

b. Disiplin Korektifyaitu suatu upaya penggerakan pegawai dalam menyatukan suatu peraturan dan mengarahkannya agar tetap mematuhi berbagai peraturan dan mengarahkannya sesuai dengan pedoman yang berlaku pada organisasi. Dalam disiplin korektif pegawai yang melanggar disiplin akan diberi sanksi yang bertujuan agar pegawai tersebut dapat memperbaiki diri dan mematuhi peraturan yang telah ditetapkan. Pedoman dalam melakukan tindakan pendisiplinan korektif adalah peringatan, segera dan secepat mungkin, konsisten dan impersonal.

c. Disiplin Progresifyaitu tindakan atau proses pendisiplinan, dimana sang manager menggunakan paksaan dan tekanan seminimal mungkin untuk memecahkan masalah kinerja. Tetapi ia akan menerapkan konsekuensi bila upaya pemecahan masalah yang lebih kooperatif tidak mendapatkan hasil. Jadi proses ini dimulai secara halus dan bersifat suportif. Pedoman dalam melakukan tindakan pendisiplinan progresif adalah teguran lisan, teguran tertulis, hukuman yang berat dan diberhentikan.

\section{Konsep Kinerja}

Bernardin dan Russel (dalam Ruky, 2002:15) memberikan pengertian kinerja Prestasi atau kinerja adalah catatan tentang hasildan yang diperoleh dari fungsi pekerjaan tertentu atau kegiatan selama kurun waktu. Menurut Gibson, dkk (2003: 355), job performance adalah hasil pekerjaan yang berkaitan dengan apa yang menjadi tujuan organisasi, efisiensi dan kinerja kefektifan kinerja lainnya. Sementara menurut llyas (1999: 99), kinerja adalah penampilan hasil kerja setiap pegawai maupun dalam organisasi. Penampilan hasil karya tidak terbatas pada personil yang memangku jabatan fungsional maupun struktural tetapi juga kepada seluruh jajaran personil dalam suatu organisasi (Ahmad, 2002).

Kinerja adalah pencapaian hasil pelaksanaan tugas tertentu, sedangkan kinerja perusahaan adalah tingkat pencapaian hasil dalam mewujudkan suatu tujuan perusahaan (Simanjuntak 2005: 1). Pencapaian sasaran dan tujuan organisasi disusun dalam unit kerja yang kecil dengan sistem pembagian kerja, serta mekanisme kerja dengan jelas.Menurut Simanjuntak (2005: 1)Kinerja adalah tingkat pencapaian hasil atas pelaksanaan tugas tertentu, sedangkan kinerja perusahaan adalah tingkat pencapaian hasil dalam rangkaian mewujudkan tujuan perusahaan.Payaman Simanjuntak(2005: 1) mengemukakan kinerja merupakan tingkat pencapaian hasil atas pelaksanaan tugas-tugas tertentu. Kinerja perusahaan adalah tingkat pencapaian hasil 
dalam rangka mewujudkan tujuan perusahaan. Manajemen kinerja merupakan keseluruhan kegiatan yang akan dilakukan dalam meningkatkan kinerja organisasi, termasuk kinerja masing-masing personserta kelompok kerja di perusahaan.Menurut Soedjana (2005: 54-55) menyebutkan 6 kriteria yang dapat digunakan untuk mengukur kinerja pegawai secara individu yakni :

a. Kualitas yaitu hasil pekerjaan yang dilakukan mendekati sempurna atau memenuhi yang diharapkan dari pekerjaan tersebut.

b. Kuantitasjumlah yang dihasilkan atau jumlah aktivitas yang dapat diselesaikan terhadap kualitas layanan yang diterima dari publik.

c. Responsivitaskemampuan organisasi untuk mengenali kebutuhan masyarakat, menyusun agenda dan prioritas pelayanan serta mengembangkan program-program pelayanan publik sesuai dengan kebutuhan dan aspirasi masyarakat.

d. Responsibilitasmenjelaskan apakah pelaksanaan kegiatan organisasi publik itu dilakukan sesuai dengan prinsipprinsip administrasi yang benar atau sesuai dengan kebijakan organisasi, baik yang eksplisit maupun implisit (Lenvine, 1990) oleh sebab itu, responsibitas bisa saja ada suatu ketika berbenturan dengan responsivitas.

e. Akuntabilitasmenunjuk pada seberapa besar kebijakan dan kegiatan organisasi publik tunduk pada para pejabat politik tersebut dipilih oleh rakyat, sehingga dengan sendirinya akan selalu merepresentasikan kepentingan rakyat. Dalam konteks ini, konsep akuntabilitas publik dapat digunakan untuk melihat seberapa besar kebijakan dan kegiatan organisasi publik itu konsisten dengan kehendak masyarakat banyak.

Menurut Lateiner dan Levine (1993) dalam Hasbar Mustafa H (2014: 42) mengemukakan bahwa indikator kinerja karyawan dapat dilihat dari:

a. Ketepatan waktu kerja, karyawan harus bekerja ditempat kerja selama jam kerja dan selesainya secara teratur.

b. Kepatuhan terhadap aturan peraturan dan sistem kerja yang dibuat serta menjadi pedoman kerja dipatuhi secara baik dan benar. c. Kualitas pekerjaan yang memuaskan pekerjaan yang dilakukan dengan kualitas tinggi dapat memuaskan yang bersangkutan.

d. Penyelesaian pekerjaan dengan semangat yang baikKinerja tidak hanya menyangkut ketaatan seorang karyawan pada perusahaan, tetapi juga menyangkut semangat dan kegairahan kerja. Setiap karyawan idealnya harus dapat bekerja dengan penuh tanggung jawab bukan keterpaksaan atau karena takut mendapat sanksi.

e. Hubungan dan komunikasi yang efektifKinerja yang baik tidak akan muncul tanpa ada hubungan dan komunikasi yang efektif antara pimpinan dan karyawan.

f. Mampu memberikan motivasiKinerja yang baik akan selalu menjadi motivasi dalam bekerja dan dihargai sebagai suatu nilai tambah seorang karyawan.

g. Tanggung jawab. Kinerja yang baik akan selalu bertanggung jawab dengan baik setiap menggunakan atau memanfaatkan asset perusahaan.

\section{B. METODE PENELITIAN}

Peneliti mengambil lokasi di Desa Timoreng Panua Kecamatan Panca Rijang Kabupaten Sidenreng Rappang.Penelitian ini menggunakan tipe penelitian deskriptif kuantitatif, dengan metode ini diharapkan dapat memberikan gambaran secara cermat, jelas dan objektif mengenai masalah yang sedang diteliti. Sedangkan dasar penelitian yang dilakukan adalah survei dimana kegiatan penelitian menggunakan kuisioner/wawancara sebagai instrument utama dalam pengumpulan data di lapangan.Peneliti menentukan Populasi dalam penelitian ini adalah

\begin{tabular}{ll} 
Staf & 6 Orang \\
Tokoh Masyarakat & 7 Orang \\
Tokoh Agama & 16 Orang \\
Tokoh Pemuda & 11 Orang \\
Tokoh Pendidik & 4 Orang \\
Kepala lingkugan & 2 Orang \\
\hline Total & $\mathbf{4 6}$ Orang
\end{tabular}

Jadi, jumlah populasi dalam penelitian ini adalah 46 orang yang berada di Desa Timoreng Panua Kecamatan Panca Rijang Kabupaten Sidenreng Rappang.

a. Sampel

Teknik sampling yang digunakan oleh penulis adalah Nonprobability sampling. 
Menurut Ahmad (2015: 141) NonProbability Sampling adalah teknik pengambilan sampel yang tidak memberi peluang atau kesempatan sama bagi setiap unsur atau anggota populasi untuk dipilih menjadi sampel.Teknik Non Probability Sampling yang digunakan dalam pengambilan sampel pada penelitian ini lebih tepatnya penulis menggunakan teknik sampling jenuh.

Teknik pengumpulan data yang digunakan adalah Observasi, Kuisioner (angket), Wawancara, dan Studi Kepustakaan,

Menurut Sugiyono (2013: 136) Skala Likert digunakan untuk mengukur sikap, pendapat dan persepsi seseorang atau sekelompok orang tentang fenomena sosial, ini telah ditetapkan secara spesifik oleh peneliti, yang selanjutnya disebut sebagai variabel penelitian.

\section{HASIL DAN PEMBAHASAN}

Uji statistik $t$ untuk menunjukkan seberapa jauh pengaruh satu variabel penjelas/independen secara individual menerangkan variasi variabel dependen berdasarkan tabel coefficients hasil olah data SPSS, maka diketahui bahwa: Nilai $t_{\text {hitung }}$ variabel Budaya Organisasi (X1) 0,969 dengan tingkat signifikansi 0,000.Nilai signifikansi sebesar $0,000<0,05$ dan $t_{\text {hitung }}$ $0,969<1,680$ maka kesimpulannya adalah ada pengaruh secara signifikan budaya organisasi terhadap kinerja pegawai di Kantor Desa Timoreng Panua Kecamatan Panca Rijang Kabpaten Sidenreng Rappang.Hasil olah data SPSS, maka diketahui bahwa: Nilai $t_{\text {hitung }}$ variabel Disiplin Kerja (X2) 0,420 dengan tingkat signifikansi 0,000 . Nilai signifikansi sebesar $0,000<0,05$ dan $\mathrm{t}_{\text {hitung }} 0,420<1,680$ maka kesimpulannya adalah ada pengaruh secara signifikan kedisiplinan terhadap kinerja pegawai di Kantor Desa Timoreng Panua Kecamatan Panca Rijang Kabupaten Sidenreng Rappang.

Hasil olah data SPSS, maka diketahui bahwa: Nilai $t_{\text {hitung }}$ variabel Kinerja Pegawai (Y) 8,083 dengan tingkat signifikansi 0,000 . Nilai signifikansi sebesar $0,000<0,05$ dan $t_{\text {hitung }} 8,083>1,680$ maka kesimpulannya adalah ada pengaruh secara signifikan budaya organisasi dan kedisiplinan terhadap kinerja di Kantor Desa Timoreng Panua Kecamatan Panca Rijang Kabupaten Sidenreng Rappang.

\section{KESIMPULAN}

1. Berdasarkan dari hasil olahan analisis regresi linier berganda menggunakan SPSS 16.0 for windows, di ketahui nilai $t$ hitung $0,969<\mathrm{t}$ tabel $=1,680$ dengan nilai signifikansi $0,000<0,05$ dengan persentase sebesar $54 \%$ maka dapat dikatakan bahwa hipotesis positif $(\mathrm{Ha})$ diterima dan hipotesis negative (Ho) ditolak. Terdapat pengaruh yang signifikan antara variabel Budaya Organisasi (X.1) terhadap variabel Kinerja Pegawai $(Y)$.

2. Berdasarkan dari hasil olahan analisis regresi linier berganda menggunakan SPSS 16.0 for windows, di ketahui nilai $t$ hitung $0,420<\mathrm{t}$ tabel $=1,680$ dengan nilai signifikansi $0,000<0,05$ dengan persentase sebesar $46,3 \%$ maka dapat dikatakan bahwa hipotesis positif $(\mathrm{Ha})$ diterima dan hipotesis negative $(\mathrm{Ho})$ ditolak. Terdapat pengaruh yang signifikan antara variabel Kedisiplinan terhadap variabel Kinerja Pegawai $(\mathrm{Y})$.

3. Berdasarkan dari hasil olahan analisis regresi linier berganda menggunakan SPSS 16.0 for windows, di ketahui nilai $t$ hitung $8,083>\mathrm{t}$ tabel $=1,680$ dengan nilai signifikansi $0,000<0,05$ dengan persentase sebesar $48 \%$ maka dapat dikatakan bahwa hipotesis positif $(\mathrm{Ha})$ diterima dan hipotesis negative $(\mathrm{Ho})$ ditolak. Terdapat pengaruh yang signifikan antara variabel Budaya Organisasi (X.1), Kedisiplinan (X.2) terhadap Kinerja Pegawai (Y).

\section{E. REFERENSI}

Ahmad, J. (2015). Metode Penelitian Administrasi Publik. Yogyakarta: Gava Media.

Ahmad, R. (2002). Sistem Manajemen Kinerja. Jakarta : PT.Gramedia Pustaka Utama.

Jauvani, R. D. (2011). Manajemen Sumber Daya Manusia untuk Perusahaan dari Teori ke Praktik. Jakarta: PT Raja Grafindo.

Mustafa, H. (2014). Menguak Perilaku Organisasi ektor Publik Antara Teori dan Aplikasi. Yogyakarta: Ombak. 
Simanjuntak. (2005). Manajemen dan Evaluasi Kinerja. Jakarta: Universitas Indonesia.

Sinambela. (2012). Kinerja Pegawai. Yogyakarta: Graha ilmu.

Sudarmanto. (2009). Kinerja dan Pengembangan Kompetensi SDM. Yogyakarta: Putaka Pelajar.

Sugiyono. (2013). Metodologi Penelitian Kuantitatif, dan Kualitatif. Bandung: Alfabeta.

Zainuddin. (2017). Teori-teori Mutakhir Dalam Perspektif IImu Administrasi Publik. Makassar : Phinatama Media(Phinisi Utama Media). 